PORTS AND WINE

Medieval piracy was often opportunistic, as sketched in the previous chapter. However, some mariners and ports were especially bellicose, and their piracies quickly developed into maritime wars irrespective of the state of affairs between the kingdoms that they were part of. Several maritime communities were often engaged in "collective" pirate wars. The Normans, Bayonne and the Cinque Ports, which I shall describe in this chapter, were frequently involved in such wars. While it is beyond the scope of this book to conduct an analysis of every bellicose maritime community in the northwestern maritime theatre, I will remark that the Flemings are abundantly represented in the complaints over piracies, and the Castilian ports waged several maritime wars against Anglo-Gascon mariners. Likewise, the mariners of the West Country, who in the following centuries acquired a reputation for piracy, are increasingly present in sources in the fourteenth century.

For the period from c. 1280 to c. 1330 , these wars seem in part motivated by the expansion of wine exports from Bordeaux. Accordingly, the latter part of the chapter is devoted to the wine trade and the installations of the merchants from the bellicose maritime communities along the coast to facilitate that trade. However, these installations also meant that mariners and merchants continually came into contact and conflict with each other, and they might also have functioned as a communications network which could have a stimulating effect on the escalation of maritime war, since the news of piracies against fellow-citizens could travel far and fast.

\title{
BAYONNE
}

The town of Bayonne is located in the southwestern part of the Duchy of Gascony at the foot of the Pyrenees in Labourd. The town centre was founded on a Roman castrum on the hill, which overlooked the confluence of the rivers Nive and Adour, the latter terminating in the Gulf of Gascony, near Capbreton, thereby giving access to the Atlantic. This castrum presumably gave Bayonne an edge over the neighbouring coastal towns of Capbreton, Biarritz, and Saint-Jean-de-Luz, all founded on sandy 
ground which made erection of fortifications difficult. From at the least the twelfth century, this allowed Bayonne to dominate these towns, which were effectively to be seen as Bayonnais subject towns. In the twelfth to the fourteenth centuries, the estimated population of Bayonne was 7,00010,000 inhabitants, who were Gascon, not Basque speakers. While their dialect was influenced by the dialect of Béarn, the maritime language included words from Langue d'Oïl, Flemish and perhaps even some Scandinavian, an indication of the influence of maritime trade on the town. ${ }^{1}$

The Labourd region was rather poor in terms of local produce. Not much wheat was produced there, and the local wines and ciders were of a rather low quality. Initially, this meant that the region could not claim a high population or riches of any significance. It was, however, rich in wood (and to a certain extent iron), and combined with the protected position near the Bay of Biscay, this meant that from an early date the Bayonnais seemed destined to take to the seas to make their fortune.

Bayonne was ruled by a council founded on the town charter used in Rouen and in northern France. In the Bayonne town charter from 1215, it was established that Bayonne was to be governed by the cent-pairs or the jurati, consisting of a mayor, twelve magistrates, twelve councillors and seventy-five peers. These men were elected for one year at a time in April, and the residing peers chose their successors. As for the appointment to the mayoral office, the jurati presented three candidates to the English king, who then chose the mayor. Upon entry to office the jurati swore allegiance to the king of England. The jurati had judicial and administrative powers, but the key figure in the local government was the mayor, who alone presided in the daily communal court. The mayor (who often had a military background) was furthermore the chief of the local law enforcement and the militia, and he handled the town finances together with the councillors. The citizens of Bayonne had a right to be judged by the mayor and the jurati, but the English king was not absent in Bayonne. The provost of Bayonne was the king's representative, and apart from being the executor of the judgements of the council, he handled the royal fiscal rights in Bayonne, even though every year he was obliged to take an oath to the town. Furthermore, there was a castellan in charge of the castle. At the end of the thirteenth century, this office was merged with the office of provost. The royal presence in the town served to maintain the peace

${ }^{1}$ Goyheneche, Eugène, Bayonne et la région bayonnaise du XII ${ }^{e}$ au XVe siècle (Bilbao, 1990), p. 178 . 
between the different oligarchic factions in the town and in part served to reward particularly loyal subjects from the factions. ${ }^{2}$

From at least the 1270s, local politics was governed by two rival parties or factions. The first was called the "aristocratic" faction by Jules Balasque. It consisted of merchants, land-owners and jurisconsults. Until 1295, the leader of the faction was the de Manx family headed by the bishop of Bayonne, Dominique de Manx. The second faction, called the "popular" party by Balasque, was made up of shipmasters, mariners and craftsmen, headed by the de Viele (or Biele) and the d'Ardyr families. ${ }^{3}$ These three and several other magnate families had been running Bayonne throughout the thirteenth century, and while Balasque uses the terms "aristocratic" and "popular", the leaders of factions were more precisely the richest and most powerful men of the town. While the de Viele and D'Ardyr families seem to have made a significant part of their wealth from maritime commerce, the so-called aristocratic faction also contained mariners and shipmasters like Miqueu de Manx (the bishop's relative who came to be a trusted naval officer of Philippe le Bel).

Throughout the thirteenth century, Bayonne faithfully supplied important naval support (ships and galleys), as well as valued crossbowmen, to the English kings' wars in France and Wales. Bayonne also functioned as a royal ship wharf where the English king ordered ships and galleys to be built for himself and his allies. ${ }^{4}$ This service continued until the first phases of the Hundred Years War, but after about 1350 the significance of Bayonne in naval terms inexplicably declined. ${ }^{5}$ The quality of the Bayonnais warriors and their bellicosity and predilection for retaliation was a product of the numerous private wars in Gascony. ${ }^{6}$

As a consequence of the maritime war with the Normans in 1292-93, the French confiscation of Gascony and the ensuing Gascon War, Bayonne was occupied by French forces from February 1294. The occupation led to an alliance between the French and the de Manx family and others of the aristocratic faction, while Pascal de Viele and several mariners had

2 Hourmat, Pierre, Histoire de Bayonne (Bayonne, 1986), pp. 58-65.

3 Balasques, Jules, Etudes historiques de la ville de Bayonne, 3 vols (Bayonne, 1862-75), II, 206 and 436, Hourmat, Histoire, p. 69.

4 Goyheneche, Bayonne, pp. $304 \mathrm{ff}$.

5 Rose, Susan, "Bayonne and the king's ships, 1204-1420", The Mariner's Mirror, 86 (2000), 143-145.

6 Vale, Origins, p. 211. Rodger claims that Bayonne, rather than the Cinque Ports, was the backbone of the English navy in the thirteenth and fourteenth centuries. Rodger, "Naval Service," p. 647. 
to flee to England, because they were implicated in the maritime war between Bayonne and the Normans and especially in an attack on La Rochelle in $1293 .{ }^{7}$ In December 1294, Bayonnais mariners under Pascal de Viele launched a surprise attack on French-occupied Bayonne. ${ }^{8}$ In a few days, the French forces and their allies in the aristocratic faction were forced to evacuate the town, and Bayonne became the only strongpoint for Edward I in French-occupied Gascony. This liberation at the hands of de Viele and the mariners meant that the aristocratic faction was more or less destroyed, as several prominent members had to flee with the French, and the remaining members suffered repercussions (loss of property and imprisonments for their suspected collaboration with and sympathy for the French) at the hands of the victorious popular faction under Pascal de Viele.

For this liberation, the de Viele family, the popular faction and the mariners were awarded privileges by Edward I. Pascal de Viele was made mayor, provost and castellan of Bayonne for the duration of the war, and he and others implicated in the attack on La Rochelle (that is, before the Gascon War broke out) were promised protection against possible future French suits in relation to this. ${ }^{9}$

Another sign of the close relationship between the Bayonnais and Edward I was that Bayonnais merchants loaned Edward $£ 45,763$ sterling, a much needed sum of money in the Gascon War which cost Edward $£ 400,000$ sterling. What is even more remarkable is that Edward actually repaid the Bayonnais between 1299 and 1304, using revenues from the English customs, one of the few loans that he ever repaid. ${ }^{10}$ From this point on, the de Viele and d'Ardyr families ruled Bayonne continuously till 1312 and indeed continued to play a significant role in local politics throughout the first decades of the fourteenth century.

However, while the Bayonnais were loyal subjects of the kings of England, their actions during and in the wake of the War of Saint Sardos show that their loyalty to the king was not iron-clad. In 1325, Edward II urged the Bayonnais to arm for war and promised them the right to keep all spoils taken from the king's enemies at sea for themselves. ${ }^{11}$ Nevertheless, the mobilisation never materialised before the truce in autumn 1325,

\footnotetext{
7 Hourmat, Histoire, p. 74, Goyheneche, Bayonne, p. 309.

8 Goyheneche, Bayonne, p. 269.

9 Champollion, I, 422-423.

10 Vale, Origins, p. 194, Prestwich, Michael, Edward I (London, 1988), p. 399.

11 Hourmat, Histoire, p. 80, Goyheneche, Bayonne, p. 305.
} 
even though the Bayonnais must have been in a state of vigilance since at least 1323 (see chapter 7), as a maritime war with the Normans was threatening to break out again. In fact, in 1326, Bayonnais mariners transported Queen Isabella and her forces to England. Thus, they actively aided in the coup d'état which deposed Edward II. Consequently, they assured themselves a prominent place in the new regime, and the mariners who transported Isabella were rewarded accordingly. ${ }^{12}$

The statutes of the Bayonnais mariners' association also express loyalty to the English Crown. The statutes of the Societas Navium Baionensium, probably from between $1206-13{ }^{13}$ stated in detail the rules of commerce and freight for the mariners of Bayonne. It was essentially an association for mutual aid and assistance intended for common freight charges and convoys for those voyaging to La Rochelle, Bordeaux, Royan and Oléron. Its statutes did not extend to those going further north to Flanders, the English Channel or England, however. ${ }^{14}$ The association swore allegiance to the king of England, rather than the town of Bayonne, even though another obvious goal was to work equally for personal profit as well as for the good of Bayonne. The association comprised two kinds of members, rectores and naute, that is, shipmasters and mariners. ${ }^{15}$ Upon entry into the association, the mariners had to swear allegiance to the shipmasters, and the masters to the custodes of the association. These custodes functioned as the financial and judicial authority of the association.

The Societas was open to all English subjects, not just Bayonnais and voisins. A voisin (or vesin as it was called locally) was the term for citizenship of Bayonne obtained either by birth, marriage with a Bayonnais(e) or by staying for a year and a day in Bayonne. In fact, if a person had stayed in Bayonne for this length of time, he was obliged to become a citizen and to swear allegiance to the mayor, the town and the king of England. The voisin was obliged to be ready to protect and defend Bayonne and never to betray a fellow voisin to a jurisdiction other than the municipal one. In return, the voisin was to enjoy the franchises and privileges, like toll-exemptions, conceded by the duke of Gascony to Bayonne. ${ }^{16}$ This had implications for trade and Bayonnais influence, as I will show below,

\footnotetext{
12 Hourmat, Histoire, p. 8 o.

13 The only known copy of the statutes is, however, from after the death of King John of England, 19 October 1216. Goyheneche, Bayonne, p. 314.

14 Rose, "Bayonne," p. 140.

15 Goyheneche, Bayonne, p. 222.

16 Hourmat, Histoire, p. 6o, Balasques, Etudes historiques, II, 370-371.
} 
and it meant that the maritime conflicts in which the Bayonnais mariners were engaged cannot be seen as "ethnic" conflicts. This also corresponds to the general picture of the multi-ethnic character of the international mariners' community. ${ }^{17}$

The primary purpose of the association was mutual assistance and division of profits for trade in convoys, which was probably the initial reason for creating the association. The Bayonnais ships were obliged to sail in convoys, usually of four to six ships, serving the purpose of protecting the members from undercutting each other's business. However, the hazards of storms and piracy also seem to have been an important impetus for the creation of the association, and the members had an obligation to help each other in case of both storm and piracy. ${ }^{18}$

The association also had a clause for military aid to the kings of England. In the preamble it is stated that mariners and shipmaster were to aid the English king against his enemies. ${ }^{19}$ Furthermore, in articles 6 and 16 it is stated that the Bayonnais should help each other valiantly on sea as well as on land, and with force when necessary, wherever they are, to the honour of the king of England. ${ }^{20}$ Finally, article 20 stated that the mariners and the masters should be armed at all times to defend against the enemies of the English kings and should be able to deliver military support to the king in war. ${ }^{21}$ While these statutes obliged the Bayonnais mariners to be ready at all times to fight the English king's enemies, it

17 Kowaleski, Maryanne, “'Alien' encounters in the maritime world of medieval England," Medieval Encounters, 13 (2008), 96-121. I do not, however, agree with Kowaleski's picture of the peaceful international mariners' "confraternity". The piracy cases treated in this book abundantly demonstrate ardent hatred and rivalries.

18 Goyhenche, Bayonne, pp. 317-319.

19 "rectores et naute navium Baionensium constituerunt inter se societatem, que dicitur Societas navium, de assensu et voluntate tocius populi Baionensium, ad honorem Dei et beate Maria et omnium sanctorum, salvo jure et fidelitate domini sui, Regis Anglie, et suorum heredum, et, cum fuerit, ad eorum inimicos infestandos." Recueil d'actes relatifs à l'administration des rois d'Angleterre en Guyenne au XIII ${ }^{e}$ siècle, ed. Charles Bémont (Paris, 1914), p. 149.

20 "§6 Porro, naves Baionenses, ubicumque fuerint, debent se juvare et auxiliare adinvicem in suis negociis et necessitatibus pro cujusque comodo et honore, ac exaltacione domini sui, regis Anglie, et suorum, viriliter et potenter. §16 Debent quoque se coadunare ubique, tam in mari quam in terra, pro suo comodo et honore domini sui, regis Anglie, sublimando, bona fide et pro bona intencione." Bémont, Recueil, pp. 150-151.

21 "Quicumque poterit, habeat immunicionem ferram; et quilibet marinarius, quicumque fuerit, custos vel... [three quarters of the line is blank in the manuscript] dominus duodecime partis navis, habeat imunicionem ferream, et alii, quicumque poterunt bono modo, vel ad minus, perpunctum et capellum de ferro, ut possint defendere [se] ab inimicis et effugare hostes domini sui, Regis Anglie, si tempus guerre ingruerit." Bémont, Recueil, p. 151. 
also meant that they were armed for pursuing personal quarrels, piracies and wars.

In the 1310 s and 1320s, significant changes in the association took place. The traditional Societas Navium was composed of independent individuals who had an obligation of mutual aid and sharing of profits. The Societas was independent of the municipal authorities of Bayonne and, formally, the town had no power over it and did not receive any direct income from it. Furthermore, at least initially, the shipmasters were also the owners of the ships, and all regulations on freight were solely the issue of the masters and were regulated amongst them. However, the economic prosperity of the thirteenth century allowed the former shipmasters to become landlocked merchants who did not have to run the risks of taking to the seas themselves any more. This meant that by the fourteenth century, the shipmasters owned an ever-diminishing part of the fleet and were reduced to the status of employees of the merchants who did not take to the seas any more. These landlocked ship- and cargo owners were subject to communal jurisdiction. Political reforms from 1317 to $1326 \mathrm{com}$ pletely changed the status of the association. Under different mayors and the provost-castellan, the association was changed so that the shipmasters now pledged loyalty to the mayor of Bayonne, not to the kings of England. The owners now took two-thirds of the proceeds of the profits, and the masters were obliged to go where the owners demanded. While the shipmaster still ruled the mariners, he, in turn, was to answer to the mayor. The fines which before went to the Societas were now wholly or in part to be paid to the town of Bayonne, with the shipmasters as the immediate executor, rather than the former custodes. Upon arrival in Bayonne, the shipmaster had to give account to the mayor by sermon of fines incurred and crimes committed during the voyage. When a person became a shipmaster, he had to swear allegiance to the mayor. Furthermore, the mayor extended the jurisdiction of the communal court to encompass the Bayonnais vessels wherever they were, and the town received half of all fines. ${ }^{22}$ These reforms also seem to have reduced the Bayonnais mariners' inclination to engage in piracy and maritime war (see chapter 7 ).

The final changes were expressed in 1326 in the decrees of mayor Jean d'Ardyr. The Societas had now effectively come under the rule of the mayor of Bayonne. ${ }^{23} \mathrm{~A}$ possible consequence of these changes is that piracy and

22 Goyheneche, Bayonne, pp. 323-326.

23 Printed in Balasques, Etudes historiques, III, 522-529. 
the will to pursue maritime quarrels by violence became diminished, as the owners, in a cost-benefit perspective, saw less attraction in piracy and an increase in the risks. In a sense, piracy did not pay any more, and this may be the final cause for the decline in Bayonnais naval importance and service after 1350 .

\section{The Cinque Ports}

The confederation of the ports of southeastern England, known as the Cinque Ports, had its origin in the eleventh century. Originally, it consisted of the ports of Dover, Hastings, Hythe, Romney and Sandwich, but in the twelfth and thirteenth centuries the confederation expanded to encompass more than thirty ports in Kent and Sussex. These later-added ports were attached to one of the original five and their privileges. However, they did not enjoy all the privileges of the "mother-port", but rather a selection of them, though later in the thirteenth century, Winchelsea and Rye were granted an intermediary status almost equal to the one enjoyed by the original five. ${ }^{24}$

It is difficult to tell how big these ports were. Sandwich has been estimated at 5,000 inhabitants in $1300 .{ }^{25}$ However, Sandwich was one of the bigger towns of the confederation; most of them were probably smaller.

The purpose of the confederation was to provide defence of the coast, mainly through the supply of ships and men to the king, and to prevent invasion of England. However, the ports themselves also had an interest in association in order to protect their privileges and their common economic interests, mainly in trade and fishing. ${ }^{26}$

The relationship of the Ports with the Crown in the thirteenth century was characterised by unruly behaviour and outright rebellion. In 1216, when the French invaded England, the Ports did nothing to stop them. Not until four months after the death of King John did they finally rally to the cause of King Henry III, and in 1217 they defeated a French fleet bringing vital reinforcements and supplies to the French forces in England. During the baronial unrest in 1260-65, they wavered in whether to support the rebels under Simon de Montfort or King Henry III. In 1264,

\footnotetext{
24 Brooks, Frederick W., "The Cinque Ports," The Mariner's Mirror, 15 (1929), 143.

25 Clarke, Helen et al., Sandwich. The "Completest Medieval Town in England" (Oxford, 2010), p. 61 .

26 Murray, K.M.E., The Constitutional History of the Cinque Ports (Manchester, 1935), p. 1.
} 
they decided for the rebels, and even after the royal defeat of the Montfortians, the Ports continued in their defiance of the king by indiscriminate piracy. When Henry III attempted to fine them for their support of de Montfort, they proceeded to attack and burn Portsmouth in retaliation. In March 1266, a settlement with the Ports was finally reached, but scant punishment was meted out for their support of the rebels. ${ }^{27}$ Ironically, while it is quite difficult to determine what privileges the Ports enjoyed in the twelfth and first part of the thirteenth century and when they were conceded, ${ }^{28}$ it seems as if it was exactly these acts of unruly behaviour which were the reason for the confirmation and expansion of the privileges of the Ports, especially expressed in the royal charter to the Ports from 1278 . This was most probably a royal initiative to buy the loyalty of the Ports.

Constitutionally, the charter of 1278 was important, since contrary to earlier charters records, it was given to the five original ports and Winchelsea and Rye collectively, and not individually. The charter granted the Ports a number of privileges due to their naval service in Edward's war against Wales the previous year. ${ }^{29}$ In the charter of 1278 , which listed the rights and exemptions of the Ports, three outstanding clauses were noted. The first was the right of the Portsmen to carry a canopy over the king at his coronation. The second was the right to "den and strand" at the annual herring fair in Great Yarmouth, ${ }^{30}$ which also meant the administration of justice over the Portsmen's "territories" during the fair. Third, these privileges were given by the Crown in return for a fixed annual quota of fifty-seven ships fully armed and manned for fifteen days' royal naval service with no charge. ${ }^{31}$ This charter represented the combination of local and royal interests, which essentially served to secure the confederation and its institutions officially. These liberties were repeated in 1290 and extended in $1298 .{ }^{32}$ In 1282 , the Portsmen served again against the Welsh,

27 Murray, Constitutional History, pp. 34-40.

28 Murray, Constitutional History, pp. 16 and 28-29.

29 Murray, Constitutional History, p. 29.

30 On Great Yarmouth, see, Saul, Anthony, "English towns in the late Middle Ages: The case of Great Yarmouth," Journal of Medieval History, 8 (1982), 75-88, Saul, Anthony, "The herring industry at Great Yarmouth c. 1280-c. 1400," Norfolk Archeology, 38 (1981), 33-43, Saul, Anthony, "Great-Yarmouth and the Hundred Years' War in the fourteenth century," Bulletin of the Institute of Historical Research, $5^{2}$ (1979), 105-115.

31 Printed in Brooks, "The Cinque Ports," pp. 190-191.

32 Murray, Constitutional History, pp. 7 and 29. 
and in the fourteenth century they fought in the campaigns of Edward II against the Scots.

While there was a difference in the specific privileges enjoyed by the individual ports in the confederation (because these depended on the terms on which they had been made affiliated members), all Portsmen could enjoy the general privileges of the confederation, especially the lucrative rights at the Yarmouth fair, the freedom from toll and the immunity from being judged at any other court but their own, the court of Shepway (see below). Furthermore, it gave a sense of unity and security, as infringements of the privileges of one Portsman essentially meant the infringement of the privileges of the whole confederation. Consequently, people would think twice before they crossed a Portsman, since potentially they could incur the wrath of the whole confederation. ${ }^{33}$

Despite the unruliness of the Ports, the kings were not without control over them. At the beginning of the thirteenth century, several judicial and administrative duties were carried out by local royal officers. The Cinque Ports' support of Simon de Montfort, however, made it clear that the royal presence in the ports was inadequate. Therefore, in 1268, a superior royal officer of the Cinque Ports was appointed. This was the warden. This title was furthermore merged with the office of constable of Dover Castle, in that the person appointed warden was also appointed constable of Dover. While these titles in theory were distinct, in practice they were united. For ease of reference, I shall henceforth call these officers the WardenConstable. The duties of the warden were essentially those of a sheriff (that is, judicial and administrative). He had little influence in maritime affairs. The purpose of the office of warden was to satisfy the needs of both the kings and the Portsmen. For the king, he functioned as a direct channel of communication and organisation of the confederation. The Portsmen, for their part, benefitted from the warden by having an official leader who could confer unity to confederation, and while the warden was royally appointed, he had to swear to uphold the liberties of the Ports before exercising his office. In itself, the commission of the warden was somewhat weak, but by combining it with the constabulary and castle of Dover, ${ }^{34}$ he obtained a fortified base in the middle of the confederation and a military force to back up his authority. Furthermore, by residing

33 Murray, Constitutional History, pp. 49-52. For an example, see CPR 1317-1321, p. 557.

34 The Castle of Dover lay outside the county and the Cinque Ports' liberty. It disposed of its own residential court, initially only for conviction of people in the constable's service. However, this court was often used by the Warden-Constable for jurisdiction in suits 
in Dover, it was easier for the Warden-Constable to control and monitor communication with the Continent. ${ }^{35}$ Thus, the office of Warden-Constable was essentially a compromise between the Ports and the king. On the one hand, it provided the king with a reliable officer with a wide range of powers at his disposal, and on the other, it provided the Ports with unity and a royal officer charged with protecting their privileges.

One of the most important charges of the Warden-Constable was his role as judge at the Court of Shepway. One of the privileges of the Portsmen was the right to be judged by their peers (that is, fellow Portsmen) at their own court. ${ }^{36}$ The court served three different interests. Firstly, it served those of the king, as it was presided over by the Warden-Constable, thus providing the king with a measure of control over the court. Secondly, the court was a source of unity for the Ports themselves, and it assured their privileges by removing them from other courts of appeal. Furthermore, the officers (that is, mayors) of the Ports were judges at the court, and the Warden-Constable could not pass judgement without their assent. Thirdly, the court served the Warden-Constable in maintaining his role as an intermediary between the Ports and the king, since as judge he strengthened the unity of the Ports by appearing as a spokesman and advocate of their claims. However, as head of the court he also preserved a measure of power for himself over the Portsmen. ${ }^{37}$ The Shepway court was primarily concerned with the interests of the king, or suits against or involving the Ports collectively. In the thirteenth century, many Portsmen claimed and received the right to plead their cases in Shepway and not at the location where they were indicted. In effect, they would only be judged by their own, and claimed immunity from being judged by external judges. In 1314, according to K.M.E. Murray, it was decided in Parliament "that the liberty [of the Shepway court] might be claimed only when Portsmen were impleaded outside their liberties for intrinsic pleas, and not in foreign pleas. This was a necessary reform as the Portsmen were using their liberties to provide shelter to criminals, and especially pirates". 38

which had taken place outside the castle area, even though this mixture of the offices was in principle prohibited. Murray, Constitutional History, pp. 102-103.

35 Murray, Constitutional History, pp. 77-93.

36 The Portsmen also disposed of the courts of Brodhull and Guestling, but we know very little about their functions in the thirteenth century. Murray, Constitutional History, p. 138 .

37 Murray, Constitutional History, pp. 6o-61.

38 Murray, Constitutional History, pp. 70-71. 
The citizens of the Cinque Ports were often termed "barons". In the early twelfth century, the title "baron" meant little more than mature men of affairs and had nothing to do with a claim to nobility. Indeed, the leading citizens of London were also called barons. However, in the latter part of that century, the term began to change to denote a socially elite group of men around a prince, even though it would not become a title of nobility until a hundred years later. ${ }^{39}$ While the Portsmen were not nobles, they maintained and defended the title throughout the Middle Ages. Murray speculates that they might have maintained this title because the position of the Portsmen was similar to that of the feudal tenant-in-chief holding his land in return for knight service, thus an indirect reference to the military service that they owed the Crown. However, she also argued that the Portsmen, in the legal and diplomatic records in the thirteenth century, were judicially associated with the magnates and clergy of England in that they, like this elite, were only to be judged by their noble peers of the English realm. ${ }^{40}$ According to Rachel Dressler, "baron" referred to the fact that the citizens held property directly from the king, ${ }^{41}$ and it is furthermore likely that the honour conferred on the Portsmen at the royal coronation bolstered at least the Portsmen's own view of themselves as akin to nobility. Thus, like the Bayonnais, they enjoyed a special and privileged judicial relationship with the English kings.

Murray and Frederick W. Brooks claimed that the Portsmen were originally fishermen, and the Portsmen's initial and primary concern was to protect their rights at the Yarmouth herring fair. Indeed, Murray assumed that this was the initial impetus for the ports to federate. Only later, in the thirteenth century, came the wine trade and freight to play a role in the economy of the Ports. Brooks, for his part, asserted that this wine trade was never very significant in the economic life of the Ports, and both claim that piracy was a significant source of wealth for the Portsmen. ${ }^{42}$ However, to my knowledge, no collective study of the economy of the Cinque Ports has been conducted, and in abundant sources documenting the activities of the Portsmen, they often seem to have been on their way to, for instance, Gascony to buy and freight wine when they conducted piracy (or were accused of it). Indeed, one of the best indications that Murray

39 Crouch, David, The Birth of Nobility (Harlow, 2005), pp. 241 and 247.

40 Murray, Constitutional History, pp. 20-21 and 30-31.

41 Dressler, Of Armour, p. 45.

42 Murray, Constitutional History, pp. 11, 17-18, 26-28, Brooks, “Cinque Ports," pp. 175 and 185 . 
and Brooks have underestimated the importance of the wine trade for the Ports is the petition of defence over Norman piracy issued by the Cinque Ports in 1293 (see chapter 4). In this document, the Portsmen explained how they had defeated a large Norman fleet off Brittany, but they claimed that they had acted in self-defence and that the Normans had harassed them for years when they went to Gascony to pick up wine.

Concerning the military service provided by the Ports for the king, it has usually been assumed that the ships supplied to the Crown by the Cinque Ports were the backbone of England's naval forces in the High Middle Ages. However, Rodger has convincingly argued that the ships of the Cinque Ports were not the most important part of the naval forces which the English kings could muster. ${ }^{43}$ This raises the question of why the Ports were granted such extensive privileges. According to Rodger, this had nothing to do with the number of ships provided. Instead, it rested on a number of practical circumstances. First of all, through their extensive piracies the Portsmen were experts in predatory actions at sea. Thus, they provided valuable service as naval experts and advisors to the kings in maritime matters. ${ }^{44}$ Furthermore, the geostrategic location of the Ports on the English coast closest to the Continent meant that the Ports were vitally important for the security of the realm, since they could effectively control the Narrow Seas. Furthermore, the Ports were the first line of defence in case of an invasion of England, and without reliable control over the Ports the enemy could land unhindered and commence devastating attacks on the English countryside. Thus, it was of vital importance to stay on good terms with the Ports, since their benevolence to the king could obstruct an invasion. The Portsmen knew this, and in large part it accounts for their unruly and self-serving actions at sea. ${ }^{45}$

As has been implied by the historians' writing on the Cinque Ports, piracy was an activity that they were continually engaged in, no doubt because of the relative judicial immunities conferred by the Court of Shepway. Indeed, according to Murray, the privileges conferred on the Portsmen were in part founded on their fierce reputation as pirates, which incidentally worked to the benefit of the English kings by discouraging naval operations against the island. ${ }^{46}$ Nevertheless, while there seems

\footnotetext{
43 Rodger, "Naval Service," p. 636.

44 Rodger, "Naval Service," pp. 644 and 646.

45 Rodger, "Naval Service," pp. 648-651, Rodger, Safeguard, pp. 124-126, Brooks, "Cinque Ports," p. 174.

46 Murray, Constitutional History, pp. 31-33.
} 
little doubt that the Portsmen were prone to piracy, we have to remain somewhat prudent as to the representativity of the sources documenting suits over piracy committed by the Portsmen. Sylvester has argued that a likely reason for the dominance of the Portsmen's piracies in the pre1348 sources is exactly the confederate status. This facilitated the victims in reprisals or suits of law against the Portsmen for the recovery of their ships and goods. Indeed, the victims would have a higher chance of success in the recovery of their goods if they impleaded the Ports collectively. ${ }^{47}$ Sylvester notes, however, that there was a marked difference between the piracies of the Ports and those of other maritime communities. The difference was the willingness of the Portsmen to act cooperatively, not just for individual goals but also to advance the interests of confederate members as well as the confederacy as a whole. Indeed, he writes that the Portsmen's duplicitous behaviour and often tumultuous relationship with the Crown is the best evidence of "port town residents who put self-interest before patriotism and the concerns of their own community ahead of those of the king" ${ }^{48}$ The best researched and most notorious instance of the Portsmen's collective piracies against a common foe is their maritime war with the mariners of Great Yarmouth. The peak of this conflict took place in 1297. Edward I had commissioned ships of the kingdom to sail his army to Flanders to confront the French. However, once the army had disembarked, the mariners of the Cinque Ports and those of Great Yarmouth manned the ships and engaged in a presumably pre-arranged naval battle. Out of the 273 ships used for the transport of the army, seventy-three came from the Cinque Ports and fifty-nine from Great Yarmouth. Thus, the battle must have been rather big. Later royal inquisitions estimated that at least 165 men were killed, seventeen ships were burned and another twelve was looted. The total damages exceeded $£_{5,000 .}{ }^{49}$ According to Sylvester, the "incidents that set off the violence were but the pretext for the deep-seated communal hatred rooted in economic competition". 50

This conflict with Great Yarmouth had been going on for a long while by the time the two sides clashed off the coast of Flanders. It seems as if the conflict began with the Portsmen's rights at the Yarmouth fair at the

\footnotetext{
47 Sylvester, “Communal piracy," pp. 166-167.

48 Sylvester, "Communal piracy," pp. 168-169.

49 Prestwich, Edward I, p. 392.

50 Sylvester, "Communal piracy," p. 172.
} 
beginning of the thirteenth century. ${ }^{51}$ Throughout the first part of the thirteenth century, they continually clashed, although never on the scale of what happened later in the century. During the Montfortian revolt, Great Yarmouth sided with Henry III against the Ports and the rebels. Edward I, on the one hand, gave privileges to the Ports, but on the other hand, he increasingly supported Great Yarmouth against them. In the 1280s, conflict between the Ports and Yarmouth grew, but the maritime war with the Norman mariners and the Gascon War put off the differences for a time. However, by 1296 conflict was about to erupt again, as Yarmouth mariners complained over being attacked by pirates from the Cinque Ports. This was in all likelihood the reason for the naval battle in 1297. After this battle, despite royal prohibitions, the maritime war continued. ${ }^{52}$ A serious impediment to the settlement of these conflicts was the Portsmen's privilege of only being able to be judged at Shepway, a place where it was unlikely that the Yarmouthmen would obtain justice. Thus, a settlement was not reached until 1305. The settlement included a confirmation of the Portsmen's rights at the fair and a general pardon for all trespasses, injuries and damages prior to 3 March 1305 . The most important point was, however, that the right to trial at Shepway presumably no longer extended to Portsmen charged with accusations of piracy. ${ }^{53}$

While the maritime war between the Cinque Ports and Great Yarmouth has been the primary focus in the studies of the Ports martial history, it should be noted that they were continually at odds with other maritime communities like the Bayonnais, the Flemings, the French, the mariners of the West Country and the Castilians.

\section{NORMANDY}

In the thirteenth and fourteenth centuries, Normandy was a wealthy and prosperous province directly under the French kings' authority. It was, however, characterised by an administrative system, a customary law and a number of privileges created by the Norman dukes and later the kings of England. In 1204, when Philippe Auguste conquered the province, he swore to respect the privileges granted to the Normans by the dukes of Normandy. While alterations and to a certain extent a deterioration

51 Brooks, "Cinque Ports' Feud," p. 30.

52 Brooks, "Cinque Ports' Feud," pp. 36-43 and 45-48.

53 Brooks, "Cinque Ports' Feud," pp. 33 and 49-50, CPR 1301-1307, p. 329. 
of these privileges occurred during the thirteenth century, as a whole the French kings respected the Norman institutions and privileges, and the Normans reciprocated by staunch loyalty to the French Crown. An example of the French kings' leniency with the Normans can be seen, for instance, in Philippe Auguste's pardon of Norman pirates after the French conquest, even though these had fought the French. ${ }^{54}$

The royal administration of Normandy was handled not by one central seneschal in Rouen, but rather a number of smaller bailiwicks throughout the province which made it easier for the Capetians to control the province. After 1220, Normandy was administratively divided into the bailiwicks of Rouen, Caen, Cotentin, Caux, Gisors, and Verneuil (which was abolished in 1302). The bailiffs had vicomtes under them, and these in turn were served by sergeants.

The Normans, however, maintained their own supreme court, the Échiquier, to administer the customary law and privileges of the province. Nevertheless, this court was presided over by the Capetian kings' trusted men, and the bailiffs were to answer to the Échiquier. For the most part, the Échiquier obeyed orders from the Parlement de Paris, and in essence it had the role of a jury which could conduct inquiries, but which usually could not pass judgement. ${ }^{55}$

However, the exigencies of Philippe le Bel and his sons' continual wars with Flanders and the consequent demands for military forces, as well as extra taxes and devaluations of the coinage in the first decades of the fourteenth century, brought changes to the power structure in Normandy (as well as in the rest of northern France). In 1315, Louis X agreed to the demands of Norman insurgents and granted them the Charte aux Normands, which limited royal rights to military service, its continual usurpation of jurisdiction in Normandy and the fiscal exigencies of the Crown in the province. One of the most important gains for the Normans seems to have been the reaffirmation of the status of the Échiquier, which henceforth was recognised as Normandy's Supreme Court, thereby barring the option of appeal to the Parlement de Paris, which had been the norm. ${ }^{56}$

54 Russon, Côtes, p. 23.

55 Neveux, François, La Normandie royale (Rennes, 2005), pp. 71-73 and 83-88.

56 Jouet, Roger,... et la Normandie devint française (Paris, 1983), pp. 118-119. However, Poirey argues that these claims were primarily judicial, not fiscal. Poirey, Sophie, "La Charte aux Normands, instrument d'une constetation juridique," in C. Bougy and S. Poirey, eds, Images de contestation du pouvoir dans le monde normand $X^{e}-X V I I I^{e}$ siècle (Caen, 2007), p. 95 . 
The Normans also supplied a rather large military force, both terrestrial and naval, to the Capetians, in addition to taxes. This naval service is the primary concern of this book. Between 1284 and 1293, Philippe le Bel constructed the Clos des Galées in Rouen to supply the Crown with its own galleys for operations in the Channel and in the Atlantic. The Clos des Galées was more of a shipyard and an administrative centre than an actual naval base (though in 1315 and 1316 fleets were assembled in Rouen and Dieppe), and while the intentions of Philippe le Bel were to build a royal fleet under the Crown, in effect it never seems that the French kings were able to build a substantial fleet of their own, not least because of the huge expenses that not only the construction but also the maintenance of a fleet entailed. In 1295, the Norman ports alone furnished approximately 150 ships, galleys and galiots of their own, thus making up more than half of the French fleet, which according to the accounts of Gyrart le Barillier was fifty-seven galleys and galiots and 223 ships. ${ }^{57}$ This is both an indicator of the large number of ships available to the Normans and their naval importance to the kings of France.

Rouen was the nexus of the province. Politically and commercially, Normandy was completely dominated by Rouen, with its massive population and position on the Seine. Rouen boasted roughly 30,000-40,000 inhabitants, and via the Seine it had contact with Paris, with its population of 80,000-120,000 inhabitants. The Seine area was thus a rich trade nexus, and was visited by numerous merchant ships every year. While the Normans after the French conquest seem to have oriented themselves increasingly towards terrestrial affairs, the Norman coast and ports remained vibrant, animated by fishing, maritime traffic and trade. The Seine estuary especially was a dynamic area, and several small and large towns clustered around it and profited from trade. ${ }^{58}$

This network of towns was dominated by the two biggest, Rouen and Caen, which had as their satellites Harfleur and Dieppe, which belonged to the archbishop of Rouen, and smaller towns like Cherbourg, Barfleur,

57 Documents relatifs au Clos des Galées de Rouen, ed. Anne Chazelas, 2 vols (Paris, 1977-78), I, 27 and 36, Jal, Archéologie navale, II, 301-19. Royal shipyards in Rouen may have an older origin, however. At least in the last years of the 119os, Richard I seems to have built galleys in Rouen. Gillingham, John, "Richard I, galley-warfare and Portsmouth: The beginnings of a royal navy," in M. Prestwich, R. Frame, and R. Britnell, eds, Thirteenth Century England VI (Woodbridge, 1997), pp. 7-8.

58 Russon, Côtes, pp. 15-16. 
Port-en-Bessin, Touques, Fécamp, Saint-Valéry-en-Caux and Le Tréport. ${ }^{59}$ Rouennais maritime commerce was based on three axes; namely England, north-eastern Flanders and the Parisian hinterland, ${ }^{60}$ but Rouennais trade also reached Iberia and the French Atlantic sea-board trading in salt, wheat and wine from Ile-de-France, Burgundy and Languedoc. ${ }^{61}$ Politically, Rouen increasingly became the centre of Normandy. From 1268, the seat of the Échiquier alternated between Rouen and Caen (population 10,000), but from 1296 Rouen became the sole seat for this court. ${ }^{62}$

Rouen was most probably run by the richest merchants in the Ghilda mercatorum of the town. During the thirteenth century, the number of these oligarchic families diminished continually, while corruption and nepotism grew. Thus, in 1292 the Rouennais rioted against the oligarchy. ${ }^{63}$ The riots were put down by the royal government, and some of the privileges of the towns were temporarily suspended, but not until $1315^{-20}$ was a more durable solution provided to what increasingly seemed like a corrupt and abusive town government. Thus in 1321, Rouen obtained a new town constitution. The governance of the town still rested with the mayor assisted by thirty-six elected pairs, but serving three-year terms instead of for life, as previously. Furthermore, the municipality was put under the surveillance of twelve prud'hommes. The mayor lost control over urban finances, which were to be managed henceforth by two pairs and two prud'hommes. This new constitution permitted the mid-level bourgeoisie to participate in the municipal government. ${ }^{64}$ Thus, in contrast with Bayonne, Rouen experienced a weakening of the mayoral powers.

I will now consider the Norman ports manifestly involved in piracy and maritime wars. Here, Rouen is curiously absent in the sources on piracy. Rather, the piratical ports were those located on the coastline from the Cotentin peninsula (including Saint-Malo, even though this was not a Norman port per se) to Picardy, although there seems to have been a concentration around the Seine estuary where Harfleur, Leure (today more or less

\footnotetext{
59 Neveux, François, "La constitution d'un réseau urbain en Normandie," in P. Bouet, and F. Neveux, eds, Les villes normandes au Moyen Âge (Caen, 2006), p. 59.

60 Sadourny, A. "Les grandes familles rouennaises au XIII e siècle et leur rôle dans la cite," in P. Bouet and F. Neveux, eds, Les villes normandes au Moyen Âge (Caen, 2006), p. 271.

61 Hérubel, M.A., Le port de Honfleur (Paris, 1926), p. 18.

62 Neveux, "Réseau urbain," pp. 56-57.

63 Mollat, Michel, ed., Histoire de Rouen (Toulouse, 1979), pp. 94-95, Sadourny, "Grandes familles," pp. 276-277.

64 Neveux, La Normandie royale, p. 467.
} 
Le Havre), Honfleur and Chef de Caux ${ }^{65}$ were located. In contrast with Bayonne and the Cinque Ports, it is difficult to ascertain exactly what kept the Norman ports acting in unison. One explanation may be that they were associated in general, as through the specific laws that had governed the Duchy of Normandy. Nevertheless, it may also simply be an informal coinciding of interests at sea that kept them united in the face of, for instance, the Cinque Ports and Bayonne, and bolstered by their naval services to the kings of France. Likewise, it seems at times as if Picard and Artesian ports like Calais united with the Normans against the Anglo-Gascon mariners. ${ }^{66}$

In a peace treaty between Bayonne and the Normans from 1282, the Norman ports mentioned specifically were Dieppe, Fécamp, Étretat, Chef de Caux, Leure, Harfleur, Touques, Ouistreham (the port of Caen), Caen (proper), Barfleur, Cherbourg and Régneville, although apparently more ports than just these were implicated in the maritime war. ${ }^{67}$ In a Norman raid against the English and Bayonnais up the Charente River, it was stated that at least some of the pirates came from Barfleur and perhaps also Leure. ${ }^{68}$ While no official leadership of these mariners is apparent, the town leaders must have known about the actions of the mariners - both to defend against accusations and to agree to peace treaties. The organisation of these ports is unknown. We do not have any documents stating any sort of a confederation like the Cinque Ports. If anything, it seems as if the "ringleaders" were probably Dieppe and Harfleur, but Fécamp, Le Tréport and Honfleur may also have played prominent roles. ${ }^{69}$ Compared with Bayonne, there is a considerable drought in sources concerning the organisation of the ports of Normandy. Thus, we have no information about their merchants', fishermen's and mariners' guilds, even though in all likelihood these ports also had maritime organisations for the freighting of goods, especially from the Ile-de-France and Burgundy, which travelled from Paris by the Seine River to Rouen and from there to be freighted by the mariners, particularly of the Seine estuary. One association is known, however, from the eleventh and twelfth centuries, namely the Sociatas whalmanorum, which had stations in

65 Today Sainte-Adresse near Le Havre. Bois, Guy, Crisis of Feudalism (Cambridge, 1984), p. 317.

66 See, for instance, the Normans' and the Calaisiens' attack on Dover. Langtoft, p. 225.

67 TNA C 47/29/2/40.

68 TNA C $47 / 31 / 5 / 1$.

69 Neveux, La Normandie royale, p. 480. 
Le Tréport, Quillebeuf, Conteville, Dives and Port-en-Bessin. ${ }^{70}$ It is unknown if these had any hand in piracy, but it seems as if Norman mariners and fishermen in general were involved in the piracies and maritime wars. In addition, the Norman coastline was ideal for piracy, as traders from the Bay of Biscay would often follow the Norman coast en route to Flanders.

In the following I will briefly examine three of these "pirate" ports, namely Harfleur, Dieppe and Regnéville.

Harfleur and Dieppe (and St. Malo) were the primary ports for pirates to dispose of their booty, and in the thirteenth and the beginning of the fourteenth century Harfleur seems to have been the primary pirate and privateer port. ${ }^{71}$ From the fourteenth century, Harfleur disposed of a fortified annex to the Clos des Galées for construction and repair of ships, and it served as a centre for Admiralty command and the assembly and departure of fleets from the Seine area. In 1295, Harfleur was the single largest contributor of ships for the royal fleet, fifty-one ships, compared to the forty-four supplied by Dieppe and the five ships and thirty-three galleys of Honfleur (however, these galleys most probably were not from Honfleur alone, but rather included a contingent of enlisted foreign galleys and possibly also some royal ones). ${ }^{72}$ The Harfleurais mariners were primarily mariners engaged in trade and freighting, whereas the Dieppois were primarily fishermen. ${ }^{73}$ Harfleur and Honfleur served as transit ports for Rouen and Harfleur, which trafficked in salt, wine transit, and coastal trade. ${ }^{74}$

Like Harfleur, Dieppe (a town of perhaps 7,00o inhabitants) was directly under the archbishops of Rouen, who had important interests in the maritime commerce of the town. The town grew rapidly in the twelfth century, and under Archbishop Eudes Rigaud (from 1247) the commercial and maritime power of Dieppe was allowed to expand. However, the port was primarily engaged in herring fishing and transport to and from England, and Dieppe seems to have been almost exclusively a port for transbordement of merchandise, that is, a safe haven and a place for reloading, provisioning and going to the big trade emporia like Bruges or London. One of the reasons for this was that the harbour was quite inaccessible and was characterised by a

70 Hérubel, Honfleur, p. 21. See also Musset, Lucien, "Quelques notes sur les baleiniers normands du Xe au XIII ${ }^{\mathrm{e}}$ siècle," in L. Musset, Nordica et Normannica (Paris, 1997), pp. 307-321.

71 Russon, Côtes, pp. 79 and 487.

72 Hérubel, Honfleur, p. 22.

73 Russon, Côtes, p. 485.

${ }^{74}$ Hérubel, Honfleur, pp. 19-20. 
treacherous current. ${ }^{75}$ Since at least the start of the thirteenth century, the Dieppois also supplemented their income by piracy. ${ }^{76}$

Regnéville, guarded by a castle, was somewhat smaller than Harfleur and Dieppe, and like Dieppe, the port was difficult to access. The water level was low, and big ships never went directly to the port but laid anchored a few miles out in the sea by the Îles Chausey. From here goods were transported in smaller boats to Regnéville with the rising tide. Nonetheless, Regnéville constituted a safe port in Basse-Normandie for mariners from the west. ${ }^{77}$ The somewhat poor port of Regnéville was not the reason for this maritime activity. Rather, it was the proximity half a mile south of the town of Montmartin-sur-Mer, which hosted the biggest fair in Basse-Normandie, and which lay on the road to the biggest Norman towns and Paris. Together, these two towns made this part of the Cotentin peninsula a commercial centre with a permanent community of Gascon wine merchants. ${ }^{78}$ Regnéville exported primarily wheat from the Breton and Caen plain and imported Spanish iron, English lead, tin and wool, and especially Gascon wine. The resident Gascons sold some wine locally or blended the wine there before sending it off to other markets. The wine customs were handled by two local citizens of Coutances, and seemingly a lot of fraud was involved in the handling of these and their fraudulent confiscations of wine to be sold off at their own profit. Thus, it seems as if wine import was quite important for the local economy, even though the Gascons presumably also came to Regnéville to buy fish. ${ }^{79}$

In contrast with Bayonne, as part of the inherently bellicose Gascony where nobles and towns enjoyed ancient rights to wage private war, since the twelfth century Normandy had been a duchy where feuds and private wars between nobles were outlawed. On the whole, this was obeyed by the Norman magnates and towns. ${ }^{80}$ Nevertheless, the hostile climate of the sea lanes makes it clear that the Norman mariners in no way held back in comparison with their Bayonnais and English colleagues when

75 Lardin, Philippe, "L'activité du port de Dieppe à travers la comptabilité de l'archevêque de Rouen," in Ports maritimes et ports fluviaux au Moyen Âge (Paris, 2005), p. 171, Lardin, Philippe, "Les transformations de la ville de Dieppe pendant la Guerre de Cent Ans," in P. Bouet and F. Neveux, eds, Les villes normandes au Moyen Âge (Caen, 2006), pp. 75 and 87-91.

76 Russon, Côtes, p. 486.

77 Le Pesant, M., "Le commerce maritime de Regnéville au Moyen Âge," in Annales de Normandie, 8eme année (1958), pp. 323-324, Russon, Côtes, p. 180.

78 Le Pesant, "Commerce maritime," pp. 330-331.

79 Le Pesant, "Commerce maritime," pp. 325-329.

80 Cazelles, "Réglementation royale," pp. 542-543, see also Yver, Jean, L'interdiction de la guerre privée dans le très ancien Droit Normand (Caen, 1928). 
it came to violently defending and expanding their trade at sea. On the uncontrolled sea lanes, the Normans were probably just as quick as their English colleagues to resort to violence and lucrative plunder by piracy. ${ }^{81}$ Russon remarks that some ports like Saint-Malo, Harfleur and Dieppe, with a strong tradition for autonomy and a significant maritime engagement, preferred to settle their scores with rivals by violence rather than by appealing to the somewhat inefficient judicial authorities. ${ }^{82}$ However, unlike the Bayonnais or the Portsmen, the Norman mariners were not continually engaged in conflicts with other maritime communities. Indeed, the struggles seem to be confined to wars with the Bayonnais and the Portsmen, and in one instance against the Flemings in the 1310s.

The lack of any clear organisation and definitive leaders of the Norman maritime wars leads one to speculate if the powerful Rouennais merchant families or the archbishop had a hand in these activities, or possibly even backed them up. While the English merchants of Barton's complaint from 1327 of the attack by the Abbot of Fécamp's men on their ship in Fécamp and their plunder of the ship and the killing of the brother of one of the merchants seems to indicate an involvement by authorities like that of the abbot, it is difficult to determine whether this was an attack of opportunity, or rather an operation of arrest of goods in reprisal for damages suffered by Fécampois mariners, which is the claim on the dorse of the document. ${ }^{83}$ Thus, we cannot exclude an involvement in the piracies by authorities like the Rouen merchants, the higher clergy or indeed the French kings, but not much evidence suggests that operations like maritime wars was directed from the top of French society.

Indeed, what unites Bayonne, the Cinque Ports and Normandy in relation to piracy was that they were directly under the king's authority, which could support the notion that they were carrying out the secret orders of the kings. However, the sources suggest that they were in fact more than capable of pursuing private goals and wars themselves without any help or incitement from the kings. Indeed, most of the time, the wars and piracies were more of an embarrassment and a problem, especially for the English, than the front line of clandestine royal ambitions. Evidence of this is that the maritime war between Bayonne and Normandy in

81 Russon, Côtes, p. 472 "la vengeance est souvent à l'origine de ces engagements semiprivés dans la guerre sur mer. [...] la mer offre un terrain privilégié à la prolongation de la vieille tradition nobiliaire de la guerre privée, avec son lot de violences et de pillages lucratifs."

82 Russon, Côtes, p. 296.

83 TNA SC 8/258/1289oA1327. 
1316-18 came at a time when neither the French nor the English king had any interest whatsoever in such a conflict, because their resources were tied up in wars with Flanders and Scotland. Thus, the Normans, like their Anglo-Gascon colleagues, seem to have disposed of a will of their own to pursue personal as well as collective goals and grievances, whether their royal overlords approved of them or not. ${ }^{84}$

\section{Wine Trade}

A significant stimulant and incitement to the use of piracy in the years 1280-1330 was the boom in the wine export from Bordeaux to northern Europe. It seems as if at least the maritime wars between Bayonne and the Normans (but indeed also between many other maritime communities) were founded on the quarrels between the mariners and merchants when they met in the ports and on the profit to be made by preying on the valuable wine cargoes, both locally when these ships passed on the coast and on long-distance trading voyages.

The wine export from Bordeaux seems to have increased steadily in the thirteenth century. Thus, in 1227, Bordeaux wine was exported to Harfleur, in 1243 to Brittany and in the years $1250-75$ it gained ground in Ile-deFrance. ${ }^{85}$ However, not until the last quarter of the thirteenth century and the beginning of the fourteenth century did the wine export from Bordeaux really expand (see figure). For instance, in 1308-9, approximately 850,000 hectolitres of wine were exported from Bordeaux, equivalent to the export volume of wine out of Bordeaux in $1938 .^{86}$ It is important to stress, though, that we do not possess data documenting the exact volume of this export until 1303. It is possible that growth in the export was not exponential, but instead was sudden due to other circumstances, amongst them a desire on the part of Edward I to invigorate trade after the Gascon War. However, as will be apparent in the following chapters, even before 1303 many mariners from northern France and England went to Bordeaux each year to freight wine north to England, Flanders and France. Thus, while we do not know the exact volume of the export for the thirteenth century, the activities of the mariners suggest that it was already in rapid expansion by that point.

84 Russon, Côtes, p. 439 .

85 Renouard, Yves (Bernard, Jean ed.), Histoire de Bordeaux, (Bordeaux, 1965), vol. 2, 247. See also Renouard, Yves, "Le grand commerce des vins de Gascogne au Moyen Âge," Revue historique, 221 (1959), 261-304.

86 Cassard, Jean-Christophe, "Les marins bretons à Bordeaux au début du XIVe siècle," Annales de Bretagne et des Pays de l'Ouest, 86 (1979), 380. 


\begin{tabular}{lccc}
\hline Year & Tuns of wine & Year & Tuns of wine \\
\hline $1305^{-06}$ & 97,848 & $135^{0}-51$ & - \\
$1306-07$ & $93,45^{2}$ & $135^{2}-53$ & 19,629 \\
$1308-09$ & 102,724 & $1353^{-54}$ & 16,328 \\
$1310-11$ & $51,53^{-1}$ & $1355^{-56}$ & 14,411 \\
$1323^{-24}$ & - & $135^{6}-57$ & 20,200 \\
$1328-29$ & 69,175 & $1357-58$ & 27,838 \\
$1329-30$ & 93,556 & $1363^{-64}$ & 18,280 \\
$1335-36$ & 74,053 & $1364-65$ & 43,869 \\
$1336-37$ & 16,577 & $1365-66$ & 36,207 \\
$1348-49$ & 5,923 & $1366-67$ & 37,103 \\
$1349-50$ & 13,427 & & \\
\hline
\end{tabular}

Figure 3.1 Wine exports from Bordeaux, ${ }^{305}-67$, including wine from the Haut Pays. ${ }^{87}$

In the first three decades of the fourteenth century, the trade in wine was almost the complete monopoly of the Gascon merchants, specifically those from the Bordeaux area, whose trade was furthermore protected by English royal privileges. The wine exported from Bordeaux was not just from that area, however. Over half of the wine came from the Haut Pays and from Languedoc. Ironically, the biggest wine exporter in Bordeaux in 1303-4 was the French king, who since 1271 had direct control over Languedoc. However, the Bordelais merchants discriminated against these wines. Thus, there were two "winefleets" a year. The first was the autumn fleet freighting the autumn harvest with the young and most precious wine, which was almost exclusively Bordelais. This fleet departed from September to November. The second fleet left after 11 November and consisted mostly of Haut Pays wine. In theory, this second fleet could leave from November on, but most had to wait till Easter the following year or even until May or June before departing due to the sailing conditions. The voyage from Bordeaux to London presumably took about two months, even though it was possible to do it faster. ${ }^{88}$ While this was the principle, James remarks that we should not understand this as only two departure times a year. Rather, in peace time, the trade was not overly organised, as several departures of singular or small groups seem to have been the norm

\footnotetext{
87 James, Wine Trade, p. 32.

88 Renouard, Histoire, pp. 247-256, James, Wine Trade, p. 123, Ward, Medieval Shipmaster, p. 232.
} 
throughout the year. Not until 1336 did convoy sailing become obligatory and permanent because of Norman and Scottish piracies. ${ }^{89}$

An indicator of the importance of the Bordeaux wine trade and its economic significance is that Bordeaux wine made up $31 \%$ of England's import and $25 \%$ of the Flemish import. ${ }^{90}$ The Gascon and primarily Bordelais quasi-monopoly on the trade made them send commissioners to the English ports, especially London, but Sandwich and Winchelsea also had big settlements of Gascons who enjoyed the same privileges as the "barons" there, and Bordelais merchants had residences in Caen in Normandy. ${ }^{91}$ Thus, every year England was visited by several hundred Gascon merchants. ${ }^{92}$ At the beginning of the fourteenth century, only a few English merchants resided permanently in Gascony, ${ }^{93}$ and while the wine trade was stabile and prosperous in the first three decades of the fourteenth century (though marked by brief declines during the AngloFrench wars), the privileges and Gascon quasi-monopoly created resentment amongst the English merchants, and Gascons periodically suffered attacks in the English ports by envious locals. At one point, in 1315, the attacks became so severe that the Gascons threatened a total boycott of England. This resentment gradually led to more and more royal privileges for English wine merchants, and in 1327 London merchants brought into the country and sold as much Gascon wine in England as the Gascons themselves. In the 1330s, the English merchants increasingly went to Bordeaux themselves to buy and freight the wine, to the detriment of the Gascons. The result was that the Gascons gradually diverted their trade to the Continental market, primarily northern France and Flanders, and from 1330 a decline began in the wine export from Bordeaux from which it would never really recover in the Middle Ages. ${ }^{94}$

In the first decade of the fourteenth century, the zenith of the Bordeaux wine export, several hundred ships visited Bordeaux each year. According

89 James, Wine Trade, pp. 16, 124 and 133. However, during wars and truces, convoys were ordered, as in 1301, when the king ordered all English ports, but especially the Cinque Ports, that when they sailed to Gascony for wine and other merchandise, the ships should continually be kept in the form of a fleet and in such depth of water at sea or in the river that they could not be attacked, taken or arrested by enemies conducting surprise attacks. When the mariners were on land, they should be cautious and behave themselves, thus making sure that further travel would be untroubled. CCR 1296-1302, pp. 499-500.

90 Renouard, Histoire, p. 257.

91 Dupont, Gustave, Histoire du Cotentin et de ses iles (Caen, 1873), p. 220.

92 James, Wine Trade, pp. 73-74.

93 Renouard, Histoire, pp. 262-264.

94 Renouard, Histoire, p. 264, James, Wine Trade, pp. 9-15, 70-76 and 81-83. 
to Cassard, 982 ships in $1303-4,610$ in $1306-7,55^{2}$ in $1307-8$ and 747 in 1308-9. ${ }^{95}$ For $1303-4$, Renouard has calculated the tonnage and origin of these ships. $81 \%$ of the ships had a carrying capacity of under 150 tons, $16 \%$ could carry between $150-200$ tons and 3\% could take more than 200 tons. ${ }^{96}$ On the origin, he writes that only six of the 982 ships that left the Gironde charged with wine were from Bordeaux, that is, $0.50 \%$. The others were English (40\%), Basques (9\%), Breton (22\%), Oleronais (3\%), Rochelais $(0.5 \%)$, Norman $(10 \%)$ or Cantabre $(5 \%) .97$ This calculation is, however, somewhat faulty. Cassard points out that the ships identified by Renouard as "oleronais" is based on Renouard's reading of de Loyre as denoting Oléron. According to Cassard, this should rather be understood as the Pay Nantais, thus as the Loire estuary. ${ }^{98}$ For my part, I have doubts as to both these interpretations as Loyre or Loyra sometimes figures in the sources as an alternative spelling of the Norman port, Leure. ${ }^{99}$ Thus, the number of Norman ships might be slightly higher than assumed by Renouard and Cassard. Likewise, it is not clear what the term basques covers. Presumably, it refers to ships from ports like Bayonne, Fuenterrabìa and San Sebastian, but Renouard gives no explanation, and we are left in the dark. In the same vein, it is also unclear what cantabres covers, and how he distinguishes between basques and cantabres. These uncertainties are not insignificant, as it makes it hard for us to assess the number of Bayonnais and Norman ships involved in the freighting of the wine. Due to the Gascon monopolies, most of these visiting ships were engaged primarily in freight of wine and not trade. This was in essence what the mariners of Bayonne, Normandy and the Cinque Ports had in common, namely that they were primarily freighters and only secondarily merchants. ${ }^{100}$

The voisinage "system" protected the Bayonnais abroad and gave security not only to Bayonnais by birth, but also those associated with voi-

95 Cassard, "Marins Bretons," p. 381.

96 Renouard, Histoire, p. 255.

97 Renouard, Histoire, p. 242: " 6 seulement des 982 bateaux qui sortent de la Gironde chargés de vins sont bordelais, soit $0,50 \%$; les autres sont anglais (40\%), basques ( $9 \%)$, bretons $(22 \%)$, oleronais $(3 \%)$, rochelais $(0,5 \%)$, normands $(10 \%)$ ou cantabres $(5 \%)$." Interestingly, this only amounts to $90 \%$ something which Renouard does not account for. This could be due to negligent notaries and general deterioration of the documents. Cassard writes on these numbers: "Le fonctionnaire ducal a omis de préciser certains noms; d'autres ont été effaces par l'humidité; certains enfins n'ont pas encore été determines avec precision: il s'agit surtout de ports anglais." Cassard, "Marins Bretons," p. 396, n. 12.

98 Cassard, "Marins Bretons," p. 381.

99 Saint-Sardos, pp. 7-10, no. 9.

100 Goyheneche, Bayonne, pp. 320-321. 
sin status, making the Bayonnais maritime enterprises bigger than what a medium-size town in Gascony would suggest. For instance, in 1307, a Bayonnais decree established that if a foreigner committed a wrong against a voisin at sea, on the rivers or on the islands (probably the archipelago centred around Oléron), his goods would be confiscated, and if the voisin was wounded or if he killed a foreigner, the town would protect the voisin if he had acted within his rights. ${ }^{101}$ While it is difficult to prove from the treaties and the petitions who the voisins were, it remains clear that the Bayonnais were actually a rather big group in maritime matters. Consequently, the conflicts with other maritime communities could have geographically wide-ranging consequences.

The extensive, international trade conducted by the Bayonnais led to installations of Bayonnais merchants more or less permanently on the coasts from Spain to Flanders. The biggest of these installations were probably in London and Bruges, where at the end of the thirteenth century eighty Bayonnais merchants resided. ${ }^{102}$ The northern Spanish ports, Bordeaux, La Rochelle, the Breton ports, the Channel Islands, Sandwich, Winchelsea and some Norman ports as well had installations of merchants, which must have swollen in the summertime when Bayonnais and Gascon mariners and merchants went abroad to conduct trade. On the French coasts, the account of a Norman attack on a Bayonnais in La Rochelle in 1324 indicates that some Bayonnais at least were temporarily settled there. ${ }^{103}$ The installations on the Channel Islands and Brittany seem to have been of vital importance to the Bayonnais, and they were central for their international northern trade, essentially constituting the "crank" between the Bayonne and the markets in Flanders and England. These areas were also important for the catching and drying of fish, especially conger eel and hake. The most important area was the drying areas in Brittany north of Saint-Mathieu, to which Bayonnais merchants acquired exclusive rights from the Duke of Brittany in $1279 .{ }^{104}$ This should be seen in connection with certain drying areas on the Channel Islands given to the prominent Bayonnais, Amat de Saubaignac, in 1278 by Edward I. Despite the ferocious war between the Bayonnais and the Normans in the

101 Goyheneche, Bayonne, p. 329. The Ancient Customs of Bayonne from 1273(?) are printed in Balasque, Etudes historiques, II, 594-679.

102 Hourmat, Histoire, p. 78.

103 Goyheneche, Bayonne, pp. 529-530.

104 Recueil d'actes inédits des ducs et princes de Bretagne (XI ${ }^{e}, X I I^{e}, X I I I^{e}$ siècles), ed. Arthur de la Borderie (Rennes, 1888), pp. 264-267. 
1290s where the Normans apparently attacked the drying areas (according to Goyheneche), in 1296 several Bayonnais merchants were still living peacefully in the northern Breton ports and had no identifiable connection with the Bayonnais accused of piracy, as shown by the report made by the Vicomte d'Avranches for Philippe le Bel. In this report, the resident Bayonnais were acquitted of accusations of hostile activities. ${ }^{105}$

We know less about the Norman installations on the trade routes, but they had a permanent presence in Bordeaux and presumably also in La Rochelle and Tonnay-Charente. Likewise, they also used the Channel Islands as an entrepôt to ship wine on to England. ${ }^{106}$ It is, however, possible that they, like the Bretons, had fewer installations than the Bayonnais, for while the Bretons had a permanent "colony" in La Rochelle in the early part of the thirteenth century, they had no presence in Bordeaux apart from the freighting of wine in particular for foreign merchants. ${ }^{107}$

The reason for the specific conflict with the Bayonnais may well be that the Normans, apart from a general interest in plunder, also wanted to hinder the Bayonnais in transporting wine to the continental markets, whereas the English mariners (though still rivals) predominantly went to England with their wine. However, even during times of hostility between the kingdoms and the maritime communities, individual merchants continued to trade in the enemies' ports, and the exact nature of the conflict lines are quite difficult to establish. ${ }^{108}$

There are thus two caveats to the study of the maritime wars, namely that they were not between the ports as united political entities, but rather that it was a conflict between their maritime communities. Even then it was not a "total" war, since commerce still continued during the wars; apparently some mariners and merchants were able to remain neutral in the conflicts, as indicated by the report of the Vicomte d'Avranches.

105 Goyheneche, Bayonne, pp. 373-377, Borderie, Arthur de la, "Nouveau recueil d'actes inédits des ducs de Bretagne et de leur gouvernement (XIII - -XIV ${ }^{\mathrm{e}}$ siècles)" Bulletin et mémoires de la Société Archéologique du département d'Ille-et-Vilaine, XXI (Rennes, 1892), $15^{2-162 .}$

106 Dupont, Histoire du Cotentin, p. 220.

107 Cassard, "Marins Bretons," pp. 379-38o.

108 Russon, Côtes, p. 439, CPR 1292-1301, p. 106. 